\title{
Corporate Responsibility Index
}

\section{El-Masry, AA}

http://hdl.handle.net/10026.1/6740

Springer Reference \& Database Publishing

All content in PEARL is protected by copyright law. Author manuscripts are made available in accordance with publisher policies. Please cite only the published version using the details provided on the item record or document. In the absence of an open licence (e.g. Creative Commons), permissions for further reuse of content should be sought from the publisher or author. 


\section{Samuel O. Idowu}

Editor-in-Chief

Nicholas Capaldi

Liangrong Zu

Ananda Das Gupta

Co-Editors

VOLUME 1

$A-C$

Encyclopedia of

Corporate Social

Responsibility 
Corporate Response to Social

\section{Demands}

Corporate Social Responsiveness (Carroll, Frederick, and Ackerman)

\section{Corporate Responsibility}

- Business Case for CSR

- Corporate Social Innovation

- Corporate Social Responsibility

- Corporate Social Responsibility in Tourism

- Institute of Business Ethics (UK)

- Institutes of Directors and CSR

\section{Corporate Responsibility (Management)}

- Sustainability Management

\section{Corporate Responsibility and Sustainability Standard}

- AA 1000

\section{Corporate Responsibility
Communication}

- Media CSR Forum

\section{Corporate Responsibility Index}

Ahmed El-Masry ${ }^{1}$ and Nahla Kamal ${ }^{2}$

${ }^{1}$ Plymouth Business School, Devon, Plymouth, UK

${ }^{2}$ ALROWAD, Dokki, Giza, Egypt

\section{Synonyms}

CR index; CRI; ESG index; S\&P index S\&P/EGX ESG index; Sustainability index

\section{Definition}

The Corporate Responsibility Index (CRI) is a management and benchmarking tool produced by UK's Business in the Community (BITC). It was developed in collaboration with BITC's corporate members.

It is designed to assist managers enhance their CSR performance and to allow benchmarking of companies on certain aspects of CSR.

\section{Introduction}

Business in the Community in the United Kingdom created the CRI in 2002. Over 350 organizations have used the tool in the UK since its creation, most of which are UK-based companies listed in the FTSE 350.

It has been argued that the essential features upon which corporations work are the management of risks, transparency of systems, and corporate ethics (Hopkins 2004). The CRI uses a standardized method and question set through which corporations can report on their ethical and environmental performance. It is an instrument and not an entire system; however, it is a successful one. It is a voluntary survey which offers a yearly benchmark of how corporations manage measure and report their corporate responsibility.

BITC defines corporate responsibility as "a company's positive impact on society and the 


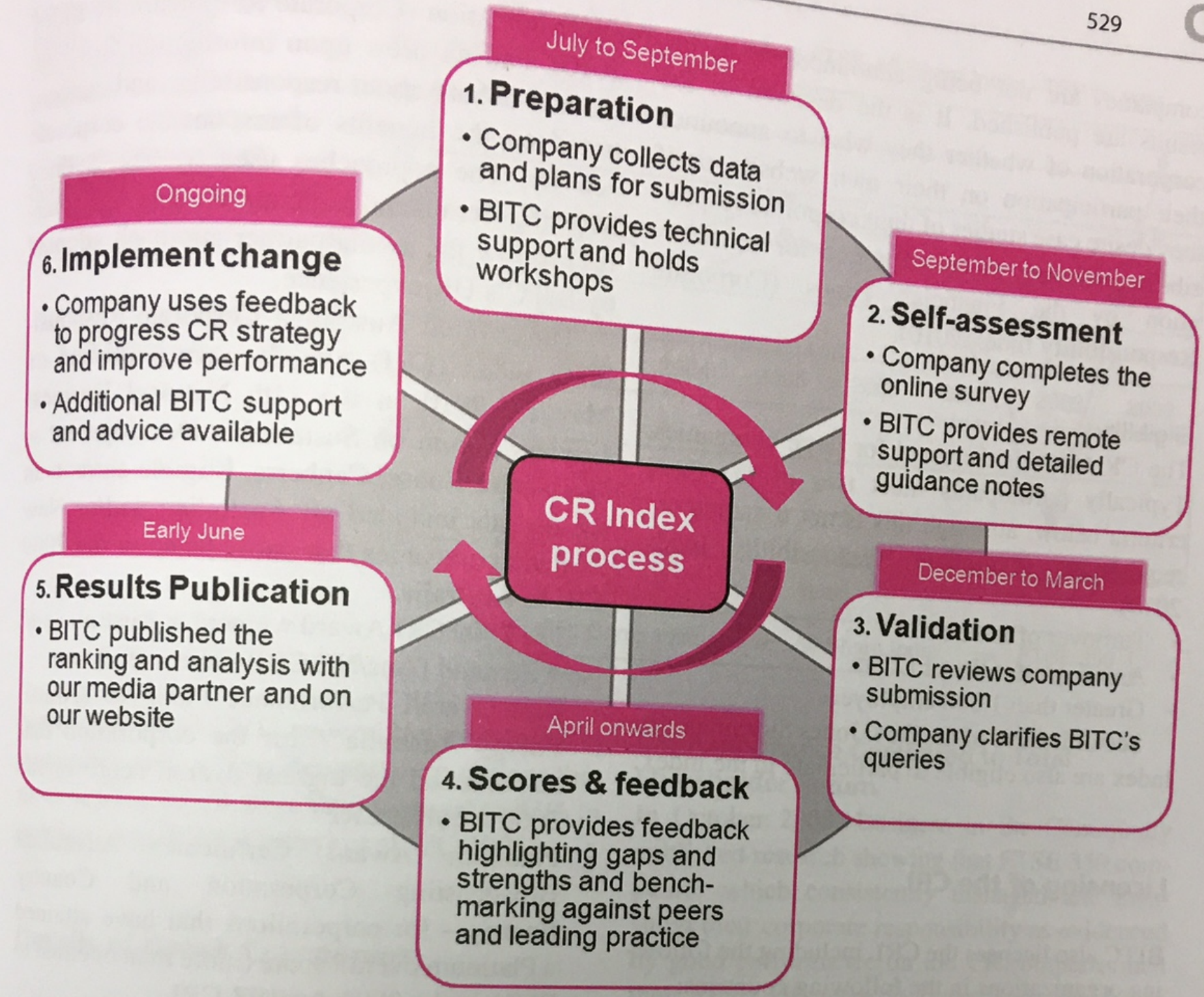

Corporate Responsibility Index, Fig. 1 The CRI annual cycle (Source: Corporate Responsibility index 2010)

environment, through its operations, products or services and through its interaction with key stakeholders such as employees, customers, investors, communities and supplies."

\section{Key Issues}

Details of the CRI
CRI Process

The CRI operates on an annual cycle. Companies

Submit a large volume of information and docu-

revie in support of their submission, and BITC

ity. The survey issions for consistency and qual-

September survey is opened online each year in

BITC mer. Qualifying corporations (mostly

and password are sent an exclusive username complete the survey. All submissions must be signed off at main board level to ensure director-level commitment to the veracity of the responses to the survey.

The annual cycle is shown in Fig. 1.

Scores and Feedback

All participants receive a feedback report explaining their performance and comparing it to their peers and the overall average. Such feedback is designed to promote better management of CSR issues and also comparison of companies against peers and other participants in the CRI. The CRI results are published each year with a media partner, currently the Financial Times. The UK participating companies are listed in an extension titled "Companies that Count" in May or June every year. The names of the participating 
companies are not being announced until the results are published. It is the decision of the corporation of whether they wish to announce their participation on their own website or if they desire case studies of their corporate responsibility practices to be submitted for consideration by the Financial Times (Corporate Responsibility Index 2010).

\section{Eligibility}

The CR Index is designed for large companies. Typically participants meet two of the three criteria below, although this is not a mandatory requirement (Corporate Responsibility Index 2010).

- Turnover of $£ 250 \mathrm{~m}$

- Assets greater than $£ 125 \mathrm{~m}$

- Greater than 1,500 employees

Sector leaders of the Dow Jones Sustainability Index are also eligible to participate in the index.

\section{Licensing of the CRI}

BITC also licenses the CRI, including the following organizations in the following countries:

Australia The St James Ethics Centre licensed the CRI from 2003 to 2009. Since 2009, some Australian companies have continued to participate in the CRI through BITC.

Greece Licensed from 2008, the Institute of Corporate Responsibility runs the CRI for Greece-based companies.

While the CRI was licensed to the St James Ethics Centre in Australia, publication of results of Australian companies was with two leading daily newspapers: The Sydney Morning Herald and Melbourne's The Age. The conditions of the contract proposed between St James Ethics Centre and Fairfax (publishers of The Sydney Morning Herald and Melbourne's The Age newspapers in Australia) officially identify an intenpurpose of the implemest practice as the main was because participants attracted to a "blame and are not likely to be informed other methods tome" game that has methods to this form of implementation (Corporate Responsibility Index 2010). Fairfax drew upon information from the broader debate about responsibility and concentrated on the benefits of responsible corporate activity. The approaches used by The Sydney Morning Herald and Melbourne's The Age (Fairfax) follow the media partner approach adopted by BITC's UK experience.

The seventh Australian Corporate Responsibility Index (CRI) Awards were published on May 27, 2010, at the 11th National Business Leaders Forum on Sustainable Development at Parliament House, Canberra. Eligible entrants in the awards included all Australian and/or New Zealand companies that participated in the 2009 CRI in Australia.

The 2009 CRI Award winners in Australia and New Zealand (Aus/NZ CRI) were as follows:

- Best Overall Performance Platinum Award: Energy Australia - for the corporation that has attained the highest overall score in the 2009 Aus/NZ CRI

- Platinum Award Certificate: Australian Broadcasting Corporation and Country Energy - for corporations that have attained a Platinum overall score (more than or equal to 95\%) in the 2009 Aus/NZ CRI

- Best Progress Gold Award: PricewaterhouseCoopers - for the corporation that has attained a Gold overall score in the 2009 Aus/NZ CRI and the highest score enhancement between 2008 and 2009

- Best Progress Silver Award: New Zealand Post Group - for the corporation that has attained a Silver overall score in the 2009 Aus/NZ CRI and the highest score enhancement between 2008 and 2009

- Best Progress Bronze Award: Western Power - for the corporation that has attained a Bronze overall score in the $2009 \mathrm{Aus} / \mathrm{NZ}$ CRI and the highest score enhancement between 2008 and 2009

The CRI Leaders' Network in Australia includes ANZ, BHP Billiton, Boral. EnergyAustralia, Rio Tinto, Toyota Australia. and Westpac Banking Corporation. In addition. Australian Broadcasting Corporation and $\mathrm{CO}^{\mathrm{ul}^{\mathrm{T}}}$ try Energy Broadcasting Corporation and Leaders 


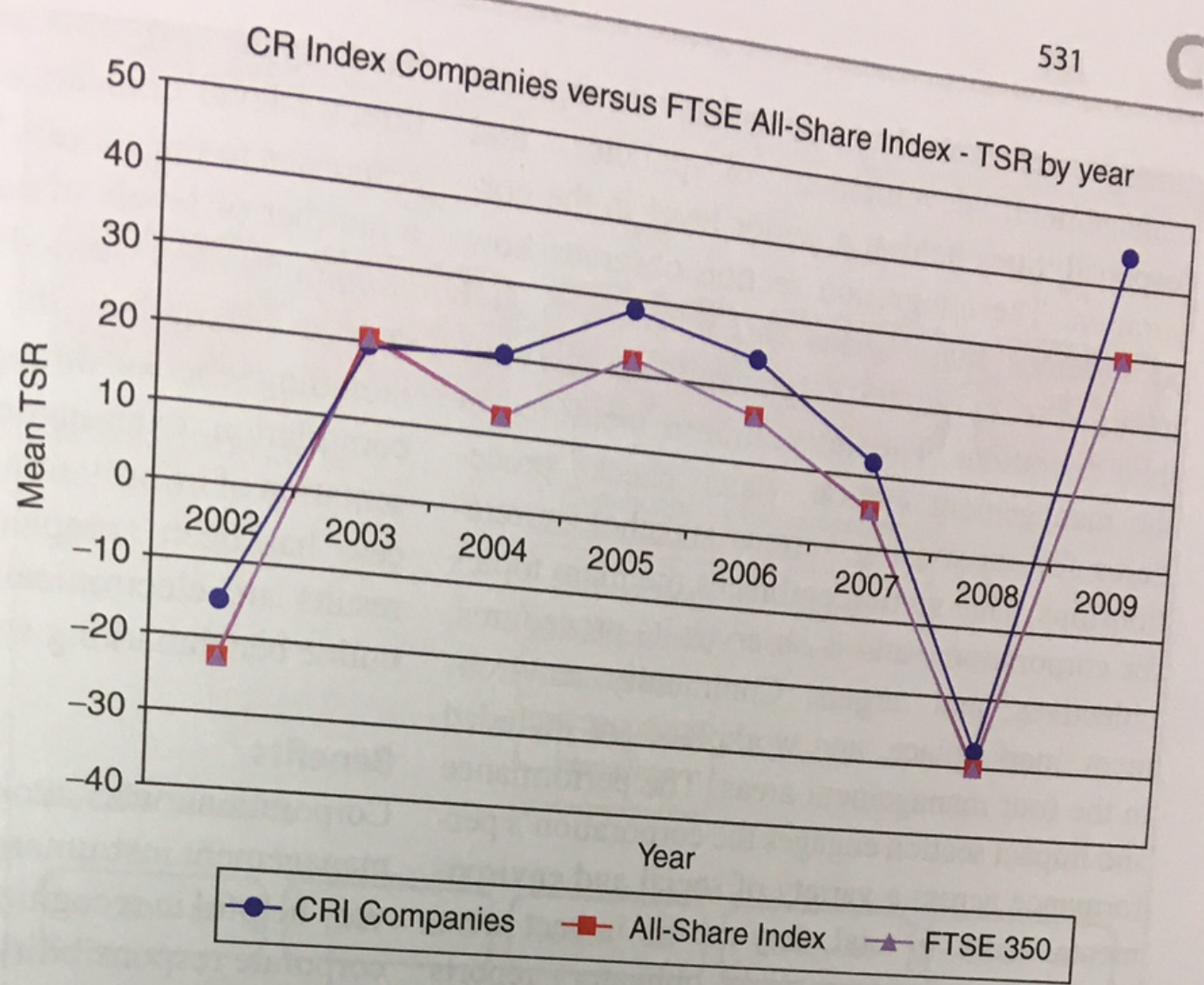

Network in 2010. CRI Leaders' Network refers to Australian and/or New Zealand corporations that have accomplished more than or equal to $95 \%$ in previous Aus/NZ CRI surveys (PWC 2005).

\section{Details of Greek Companies}

\section{Brief History}

The CRI was established in collaboration with over 80 leading UK corporations and with UKbased nonprofit organizations.

There has been a tremendously positive response from corporations, investment fund managers and city analysts, pension funds, insurers, government, and the public. Over 100 corporations have participated in the Business in the Community (BITC) Index every year from the time of its establishment. For instance, in 2004, 500 companies were asked to join in. 139 corporations of these finished the index, which represents $14 \%$ increase compared to 2003 . Essentially the 139 embrace the majority of the biggest corporations in UK (PricewatercooPershouse 2005). Companies which have are Anglo Platinum for their global operations com, Rio American, BHP Billiton, British TeleUnilever Tinto, Tata Consultancy Services, 
strategy, and how they are tackled through its management, development of policies, and responsibilities held at a senior level in the corporation. The integration section observes how corporations make plans for, administer, and incorporate corporate responsibilities all over their operations. This integration is measured in the management section, which checks procedures for supervising various stakeholder relationships. This section embraces the main topics for corporations, and it observes its procedures, objectives, and targets. Community, environment, marketplace, and workplace are included in the four management areas. The performance and impact section engages the corporation's performance across a variety of social and environmental areas. In total, they are six impact areas where all corporations make obligatory reports on two environmental impacts: global warming or energy and transport together and waste management.

Also corporations are asked to choose two social impacts obtained from product safety, occupational health and safety, human rights and the supply chain, diversity in the workplace, and community investment as well as two additional self-selected impact areas that matter to the corporation. The score of the survey is set by summing up the marks of the five sections, as shown in the diagram below where $10 \%$ of the total score is awarded to the corporate strategy section; $22 \%$ of the total score is awarded to the integration section; $26 \%$ of the total score is awarded to the management practice section, including community, environment, market$36 \%$ of the totalkplace management sections; mance and impact social and envirution, including a choice of last $6 \%$ of the total ance and disclosure sections arded to the assurthat each management It should be noted environment, marketplace, and of community, well as each of the social and workplace, as impact areas, is equally weighted environmental ration is accossment process, and every reprefindings by CEO or through the board m index handling the corporate responsibility to guarante director-level dedication to the reliability of th responses to the survey. The index process offer a number of levels of assurance. Business in the Community has worked through a validation pro. cess to strengthen the honesty of the index, including checks throughout key stages in the compilation, examination, aggregation, and presentation of information. Once the validation process has been completed by corporations, the results are electronically published by BITC's online benchmarking system, as shown in Fig. 3.

\section{Benefits}

Corporations who adopt the CRI as an internal management instrument have discovered that it is very helpful in recognizing how the integration of corporate responsibility offers the opportunity to add value to the corporation. Here are some comments of different directors using CRI in their corporations (bitc.org.uk):

- Mark Johnson, Chief Executive Officer of PricewaterhouseCoopers (PwC), stated that "Corporate Responsibility is an integral part of our business - it is not a sideshow. PwC's corporate responsibility commitment includes our contribution to the community, protecting the environment, creating the right culture for our people and embedding these values in everything we do. The CRI helps us to not only measure our performance but to be transparent in our results."

- Craig Murray, the Managing Director of Country Energy, says: "At Country Energy corporate responsibility is integral to our corporate strategy. The CRI process provides independent and comprehensive feedback on how well we are doing relative to our internal targets as well as to industry best practice. Our progress in the survey has been a pleasing reflection of the company's commitment to corporate responsibility principles."

George Maltabarow, the Managing Director of Energy Australia, states: "An independent benchmark like the CRI is the best way for a company to truly gauge its performance in key areas like the community and environment. Using the community and envirove 
Corporate Responsibility

Index, Fig. 3 Online

benchmarking system

(Source: BITC 2010)
SECTION LEVEL:- 533

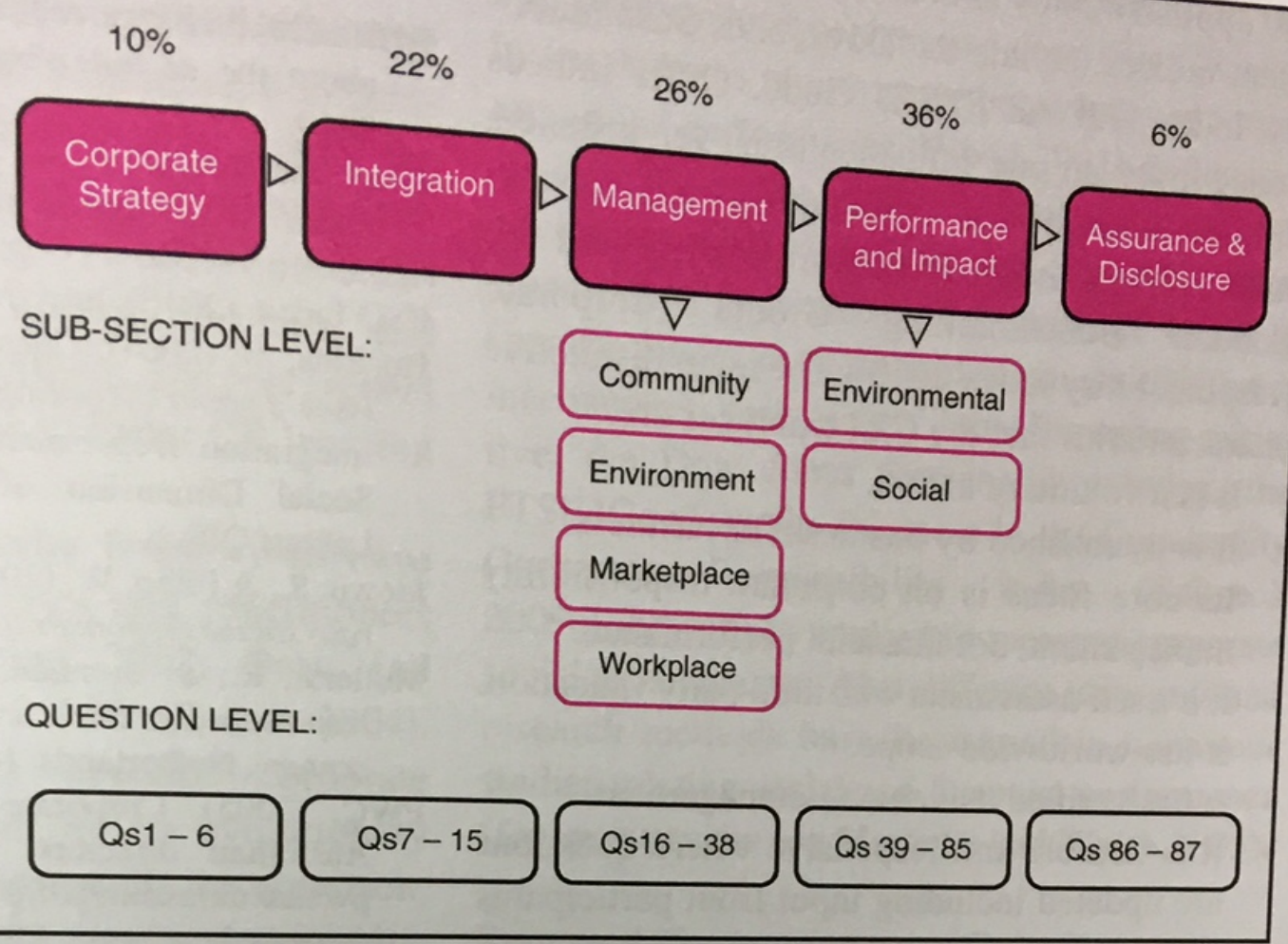

year after year and shows our commitment to doing the right thing."

Consequently, CRI provides the participating corporations with several benefits (bitc.org.uk):

1. It helps corporations improve, execute, and assess their responsible practice and assists corporations in creating a corporate responsibility issues into corporate strategy.

2. By identifying what responsible corporation means in practice, the Corporate Responsible Index helps to set the management and reporting criteria against which corporation will be judged.

3. It challenges whether the corporation is performing its activities in an organized and integrated way and directs companies through the process of integration.

4. It brings various functions in the corporation together to comprehend and manage the key CSR issues for the business.

5. It provides corporations with a practical gap analysis through a confidential feedback report, stressing on parts of great performance and spotting where enhancements need to take place.

6. It is a benchmark that permits corporations to contrast their performance inside and across divisions thm periormance over time, comparing progress to that of industry peers and the wider universe of all other participants, and showing cases and sharing best practice publicly or through the optional "mutual disclosure" tool - companies are ranked and results are published annually in the Financial Times, which reaches 500,000 readers daily.

7. It offers a communication tool with various stakeholders both internal and external, which creates transparency and builds trust. This is achieved by enabling more direct and focused commitment with stakeholders; by regularly assisting stakeholders to understand the corporation such as its operations and the constraints it faces and, on the other hand, assisting the company to understand its stakeholders, for instance, their perceptions and issues of importance; and by also helping in creating trustable and long-lasting relationships.

What Differentiates CRI from Other Indices? The CRI is the only voluntary, business-led benchmarking index which embraces all corporation divisions and reports on the four basic influence sections of corporatetace, and envicommunity, workplace, mas a business instrument ronment. The CRI works as a businent. Indices that

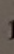


are applied mainly as socially responsible investment indices include the Dow Jones Sustainability Index and the FTSE4 Good. Other indices concentrate on one influence area, for instance, climate change and community, respectively, such as the Carbon Disclosure Project and the London Benchmarking Group (Corporate Responsibility Index 2010). The main distinctive characteristics that the CRI embraces are:

- It is a voluntary action.

- It is established by business for business.

- Its core focus is on corporate responsibility management, not financial performance.

- It is a self-assessment with third-party validation.

- It has worldwide scope.

- It has verified its value to management.

- It is flexible and responsive where questions are updated including input from participants and reference groups from corporations and society groups.

\section{Other Indices}

Other indices exist in other countries, including:

- Dow Jones Sustainability Index

- FTSE4Good

- ESG Index (Egypt)

- CSR Index (Estonia)

- Sustainability Index (Latvia)

\section{Future Directions}

Further research could be based on analyzing the experience of a wider list of corporations using the CRI and what value it adds to them compared to other companies.

\section{Cross-References}

Business in the Community (UK+Derivatives)
Corporate Governance

Corporate Social Responsibility

Dow Jones Sustainability Indices

- ESG Index

FTSE4Good Index

S\&P Index

S\&P/EGX ESG Index

\section{References and Readings}

BITC. (2010). Retrieved from www.bitc.org.uk/cr_inde about_the_cr_index/index.html. Accessed on Sep 2010.

Corporate Responsibility Index. (2010). Available fro http://www.corporate-responsibility.com.au/. Access on Sep 9, 2010.

ESG Index. (2010). http://www.ecrc.org.eg/Index.aspx Hopkins, M. (2004). Corporate social responsibility: issue's paper (Working Paper No. 27). Geneva: Poli Integration Department, World Commission on t Social Dimension of Globalization, Internation Labour Office.

Idowu, S., \& Filho, W. (2008). Global practices of corp rate social responsibility. Berlin: Springer.

Mullerat, R., \& Brennan, D. (2005). Corporate soci responsibility: The corporate governance of the 21 . century. Netherlands: Kluwer Law International.

PWC. (2005). Corporate responsibility: A guide fc Australian directors. Retrieved from http://ww pwc.co.uk/assets/pdf/pwc-annualreport2005-full.pd Accessed on Sep 3, 2010.

www.ipsos-mori.com. Accessed on Sep 9, 2010.

\section{Corporate Responsibility Maturity}

Heiko Spitzeck

Doughty Centre for Corporate Responsibility, Cranfield School of Management, Cranfield University, Cranfield, Bedford, UK

\section{Synonyms}

Corporate responsibility maturity; Developmental corporate responsibility; Evolutionary corporate responsibility

\section{Definition}

Corporate responsibility (CR) maturity describes the state of responsible business practices of an organization. Different stages of corporate responsibility maturity are distinguished alon: an evolutionary/developmental process fro basically none to exemplary practices. 